\title{
Using intrinsic vulnerability and anthropogenic impacts to evaluate and compare groundwater risk potential at northwestern and western coastal aquifers of Sri Lanka through coupling DRASTIC and GIS approach
}

\author{
Ratha Phok ${ }^{1,2}$ - Nandalal Kosgallana Duwage Wasantha ${ }^{2} \cdot$ Weerakoon Sumana Bandara $^{2}$. \\ Pitawala Herath Mudiyanselage Thalapitiye Gedara Amarasooriya ${ }^{3}$. Dharmagunawardhane Hingure Arachchilage ${ }^{3}$
}

Received: 21 September 2019 / Accepted: 11 June 2021 / Published online: 22 June 2021

(c) The Author(s) 2021

\begin{abstract}
Groundwater vulnerability assessment has become a crucial step in successfully protecting groundwater against pollution. An attempt of this study has been made to evaluate groundwater contamination risk using intrinsic vulnerability and land-uses in Vanathavillu, Kalpitiya and Katana area in Sri Lanka, using coupled DRASTIC with GIS as feasible methodology. The findings reveal that the groundwater in the areas under study falls under very low to high contamination risk. The higher risk of contamination has been identified in most of the Kalpitiya (about 82\%) with the moderate along the beach in the west and next to Puttalam lagoon in the northeast and southeast. This is mainly due to pollution risk inherent with intense vegetable cultivation, over pumping, shallow groundwater tables and permeable sandy soil. Vanathavillu is under very low to moderate contamination risk, in which the moderate risk (about 13\%) has especially been found the center, central southwest and west of the area. The relative less deep groundwater tables, possible seepage from the underlying limestone aquifer and less permeable red earth soil could be cause for the moderate risk in the area. Furthermore, results show that the Katana has low to moderately high groundwater contamination risk. Nitrate has a good agreement with the different pollution risk classes and that nitrate can be used as an indicator of aquifer degradation inherent with land-use activities in the coastal areas. Groundwater quality monitoring network should be set up to minimize the anthropogenic acts, particularly in high and moderate contamination risk zones.
\end{abstract}

Keywords Groundwater vulnerability $\cdot$ DRASTIC $\cdot$ GIS $\cdot$ Contamination risk $\cdot$ Anthropogenic acts $\cdot$ Nitrate

\section{Introduction}

As with any other commodity, for water the target is "the more, the better." Fresh water, in sufficient quantity and quality, is essential for all aspects of life and sustainable development. The human rights to water are widely recognized

Ratha Phok

rathaphok0621@yahoo.com

1 Department of Water Resources and Rural Infrastructures, Institute of Technology of Cambodia, Phnom Penh, Cambodia

2 Department of Civil Engineering, University of Peradeniya, Peradeniya, Sri Lanka

3 Department of Geology, University of Peradeniya, Peradeniya, Sri Lanka by Member States. Water resources are embedded in all forms of development. At the same time, water scarcity and stress affect over 2 billion people around the world due to population increase and climate change. In 2015, the United Nations (UN) proposed 17 sustainable development goals among which one of them is Goal 6 focusing on ensuring water security for all and needs us to take action (Tengberg 2015; Gupta and Vegelin 2016; Kumar et al. 2018). In this sense, in addition to surface water, inclusion of groundwater with integrity of the advancement and legitimate administration is considered to achieve universal access to drinking water and sanitation, leading to water security for sustainable environment and development.

Groundwater (GW) demand has been extremely increased for drinking, agriculture, and industries. However, various negative impacts on GW, in terms of quality 
and quantity, have also simultaneously been encountered, due to ever increase in anthropogenic stresses (i.e., urbanization, fertilizer and pesticide application, and sewage disposal) (Zaporozec 2002). Arid and semi-arid regions like northwestern and western coastal aquifers of Sri Lanka are threatened and susceptible to contamination in combination of diverse pollution sources, which endanger GW (Jayasingha et al. 2011). The predominant contaminants like nitrate, chloride, and phosphate have been found to have high concentrations and often exceed the water quality standard limits, particularly due to fertilizers, agrochemicals and poor sanitation (Lawrence et al. 1988; Kuruppuarachchi and Fernando, 1999; Jayasekera et al. 2008 and 2011). In general, pollution activities can be anthropogenic and natural. Continuous contaminated land from unsustainable developments can seriously cause future contamination and may lead to severe health hazards and consequently to waterborne diseases. Once contaminated, restoration of water quality is very difficult and remediation is too costly and often impractical (Zaporozec 2002).

In this context and inherent with the increasing reconnaissance of the importance of GW resources, efforts are rising and essential to have proper protection, improvement, development, and management plans to use GW sustainably. Assessment of GW vulnerability (AGV) has served as an important step to successfully develop GW protection strategy, sound management and planning against pollution. The term "vulnerability" was initiated in 1980s in France and defined as the intrinsic characteristics that will determine the sensitivity of various parts of an aquifer to being adversely affected by an imposed contaminant load (Vrba and Zoporozec 1994; Foster et al. 2002). When the areas that are most vulnerable to contamination are identified, resource managers can prioritize such areas which need supervision against human acts. One should bear in mind that all GW is vulnerable. However, because of heterogeneous properties of geological formation and aquifer systems, the sensitivity to pollution on sub-surface environment is unequal (Mato 2002). Some areas give better protectiveness from contamination than others (i.e., clay media is more protective from contamination than sand media). It is reasonable to differentiate, evaluate and compare the vulnerability degrees based on the heterogeneity. The vulnerability is a non-measurable, dimensionless and non-absolute property (i.e., the tendency or likelihood of contamination occurring), but a relative indication of where contamination is likely to take place. An $\mathrm{AGV}$ is thus a predictive statement as weather prediction, yet underground occurrence takes over very longer period and mostly beyond human control. GW vulnerability incorporates both the concepts of intrinsic and specific (integrated) aquifers' vulnerability.
To evaluate the GW vulnerability, a number of methodologies have been developed, but only three categories have been recorded, including Statistical Methods, ProcessBased Simulation Models, and Index and Overlay-based methods (NRC 1993; Kumar et al. 2015, 2020). Statistical methods use statistics to determine associated mapping between the spatial distribution of contaminants and characteristics of contaminant potential sources with which the contaminants may migrate to the position in the flow system where the groundwater sample is taken. Statistical approaches are not generic in nature as they are mostly used in the assessment of groundwater where similar contaminants are present. Process-based techniques employ simulation models to forecast pollutant movement in groundwater. The limitations of the process-based method are availability of adequate data and quality for the capture of physical, chemical, and biological reactions, but they are more elaborated than simple index-based techniques. Index-based techniques have the advantages overcoming all limitations of the two. Index-based techniques are not encumbered by computational complexities and data shortage. This is the reason that index-based methods are the most suitable for the groundwater vulnerability assessment (Kumar et al. 2015).

In index-based models, another three categories, including parametric, nonparametric, and hybrid models) are divided (Kumar et al. 2020). DRASTIC model, one among them, is the most widely used tool for GW vulnerability assessment. Development of this model was firstly by Aller et al. (1987) at National Water Well Association Dublin, Ohio in collaboration with U.S. Environmental Protection Agency (USEPA) to evaluate groundwater vulnerability to contamination potential using hydrogeological parameters. Since then, there are modifications made on DRASTIC model through various approaches categorized under index-based methods, which are in chronological order of development (Kumar et al. 2015, 2020). In the summary of Kumar et al. (2015) and Kumar et al. (2020), they include GOD (1987) developed in same year as DRASTIC followed by AVI (1992), SINTACS (1994), GLA (1995), SEEPAGE (1996), EPIK (1999), Hazard-Pathway-Target as nonparametric model (2002), Indicator Kriging (2002), PI (2005), ISIS as hybrid model (2007). Another pragmatic-parametric model named as SVV was developed by Putra (2007) and after used by Ratha (2015). These models have been applied and modified depending on different regions and hydrogeological settings with reducing parameters used compared to DRASTIC. More deep details about these techniques can be referred to Kumar et al. (2015); Kumar et al. (2020).

DRASTIC model, one among them, is the most widely used tool for GW vulnerability assessment. It is classified under Overlay and Index method and has been successfully applied in many parts of the world including arid and semi-arid regions (Zhang et al. 1996; Babiker et al. 2005; 
Yin et al. 2012). The DRASTIC was originally devised as a standardized easy-to-use technique for assessing $\mathrm{GW}$ vulnerability to contamination potential based on various hydrogeological factors. The purpose of the DRASTIC is to create vulnerability index maps generated in GIS tool based on semi-quantitative data layers derived from the assignment of ratings, weights and ranges of hydrogeological parameters. The ability of GIS is to deal with query, storage and display of spatial data and the link to numerical rating systems (Ducci 2010). A vulnerability index is ultimately used to prioritize the areas into subdivisions showing different potential as low, moderate and high vulnerability zones, which are useful for GW protection, monitoring and investigation. It gets preferred among numerous approaches due to its capability to display all hydrogeological properties to a final map, which also enables the results by comparing GW pollutants like nitrate, chloride, TDS, etc. (Joshi and Gupta 2018). The final vulnerability map is then used to inform and educate the public, especially non-expert people who can catch their concepts. In spite of its popularity, the original DRASTIC proposed by Aller et al. (1987) produces some deficiencies since the weights and ratings of the factors are assigned based on pre-assigned and judged values through experts, respectively, which create subjectivity. To better resolve local issues for local hydrogeological settings, researchers have tried to propose sensitivity and modification of the parameters to check its suitability and validity and hence the subjectivity can be reduced (Lodwick et al. 1990). The DRASTIC can only produce intrinsic vulnerability maps based on existing hydrogeological data. Considering novelty of the work, the fact indicates that the modification was made by coupling with the intrinsic vulnerability and land-use factor through inclusion of anthropogenic acts to develop integrated (specific) vulnerability map showing GW risk and then validate against actual contaminant like nitrate in GW (Al-Adamat et al. 2003). Thus, the modification is to derive versions of fundamental DRASTIC using scientific consideration of anthropogenic factors and the optimization of weight and rating vectors for a comprehensive assessment of vulnerability of groundwater to contamination and denoted it as DRASTICL (Kumar et al. 2017).

Most previous research in various regions of Sri Lanka has been carried out to characterize the impact of groundwater quality from anthropogenic sources, but not much tried with the detailed assessment of groundwater vulnerability to predict and delineate the groundwater protection area of the area by determining their natural vulnerability against the contaminant from acts of human using GIS-based DRASTIC method/model. Up to now, several applications of DRASTIC method have been studied at some areas of Sri Lanka such as Kalpitiya peninsula and part of Puttalam area at the northwestern coast (Jayasekera et al. 2008 and 2011), Kalpitiya and Mannar area at the north-western coast (Jayasingha et al.
2015), Jaffna peninsula at the northern coast (Vithanage et al. 2014), and Walawe River Basin at the southern region (Ranjan 2005; Sarukkalige et al. 2007). Even though there are several studies on application of DRASTIC method, it could provide some conceptual clues and light to compose a comprehensive research at the north-western and western coastal aquifers, particularly Kalpitiya Peninsula, Vanathavillu Basin, and Katana area.

GW resource in northwestern and western coastal Sri Lanka pivotally performs, so that the need for protection has been increasingly recognized. This study aims at portraying and delineating intrinsic GW vulnerability on map by comparing the vulnerability levels between the areas of Vanathavillu, Kalpitiya, and Katana, based on their existing hydrogeological settings through coupling DRASTIC method with GIS. An additional objective is dedicated to evaluate integrated vulnerability to identify pollution risk, which is the combination of the created vulnerability map and land-use rating map followed by validation against nitrate to check the suitability of the method used. It is anticipated that the GW of the areas is susceptible to pollution from low to high, from which the proper management needs to be set up, especially for the high vulnerable zones.

\section{Study areas}

Unlike other areas of Sri Lanka, the northwestern and western coastal area with high density of population is nearly reply upon the groundwater for many purposes. The DRASTIC analysis gives the state of vulnerability and the potentially vulnerable areas (Babiker et al. 2005). It is well noticed that the use of DRASTIC model is more appropriate for the areas where it gets diversified parameters (Rahman 2008). Hence, it may be questionable about the suitability of application of DRASTIC for illustration the vulnerability of sandy coastal aquifers when considering the conditions in the study areas. This is due to the notable nature and unique areas in terms of geological conditions that specify the northwestern and western coastal aquifer systems characteristically from other coastal aquifers. It is obvious since many components (mainly intrinsic properties of aquifer system) are highly favored and vulnerable for the contamination of any pollutant. Therefore, based on literatures of the study areas hydrogeologically situated at coastal zones and on unconfined and semi-confined aquifers characterized by their shallow nature and sandy and limestone aquifer media, the DRASTIC method is thus suitable to be used to predict and delineate the groundwater vulnerability of the study areas with reference to Vanathavillu, Kalpitiya, and Katana area (Fig. 1). 


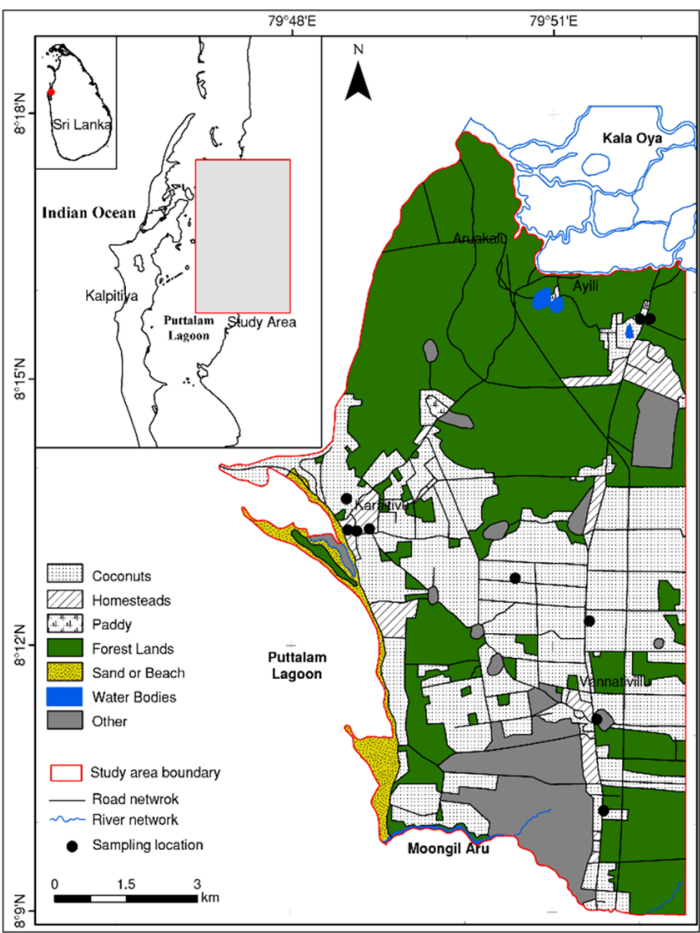

(a)

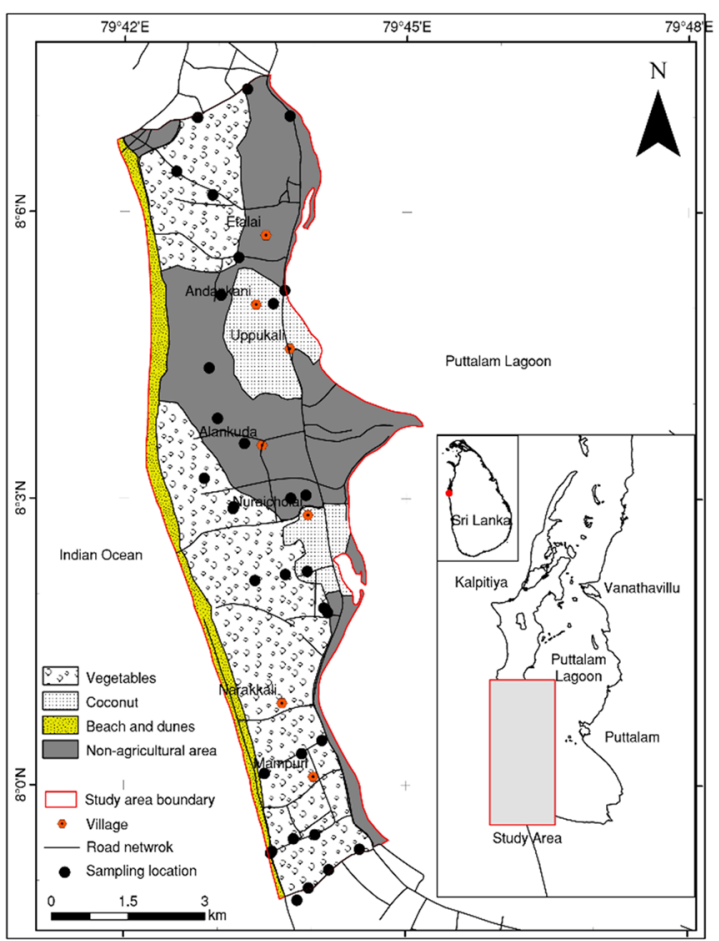

(b)

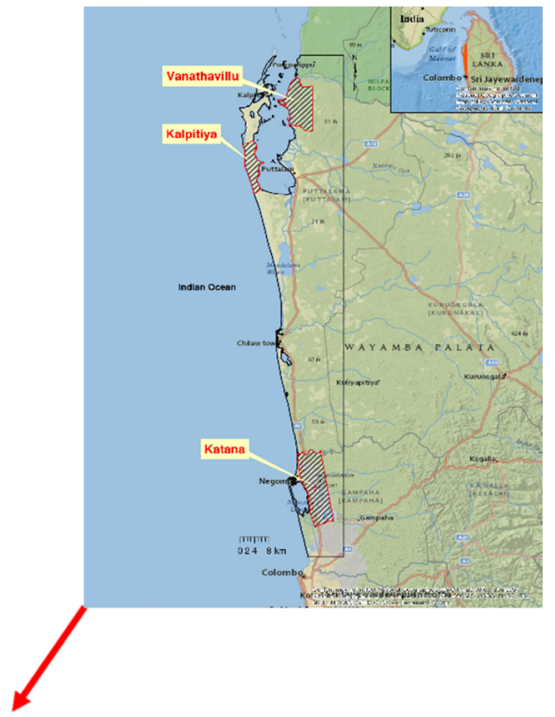

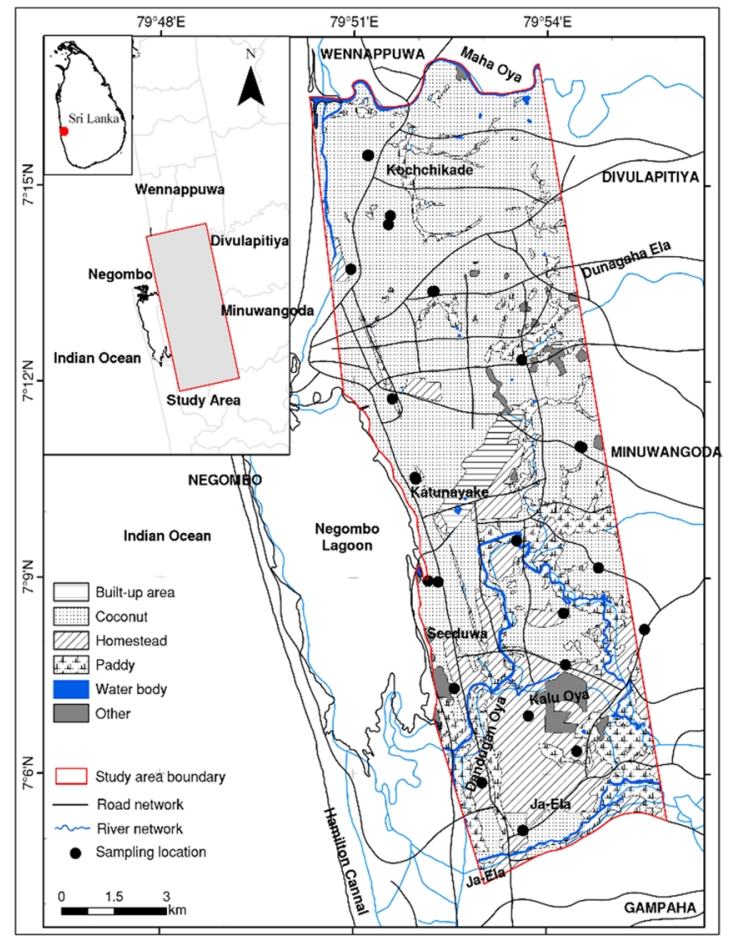

(c)

Fig. 1 Location of a Vanathavillu, $\mathbf{b}$ the Kalpitiya, and $\mathbf{c}$ the Katana 


\section{Vanathavillu area}

Vanathavillu is geographically located at about $18 \mathrm{~km}$ north of Puttalam area belongs to northwestern coast of dry zone, with coordinates of $8^{0} 9^{\prime}-8^{\circ} 18^{\prime} \mathrm{N}$-latitude $79^{0} 47^{\prime}-79^{\circ} 53^{\prime}$ E-longitude. The area covers about $93 \mathrm{~km}^{2}$ bounded by Puttalam lagoon in the west and two river systems flowing from the east to the west, Kala Oya in the north and Moongil Aru in the south (Fig. 1a), with an estimated population of 17,871 (Annual Performance Report and Accounts 2016). Majority of the area is dominated by coconut and forest lands followed by a lot of small farms and homesteads scattered throughout the area. This area is low-lying and has a subdued relief underlain by Miocene limestone, with the elevation 0-65 $\mathrm{m}$ above mean sea level (amsl). The higher elevation is in the east, southeast and northwest of the area, while the rest is close to see level in the north, west and southwest. The area experiences high temperature throughout the year $\left(27.5^{\circ} \mathrm{C}\right)$ and receives a rainfall of $1204 \mathrm{~mm}$ per year (Department of Census and Statistics 2016). Mean annual relative humidity is about $80 \%$, while the estimated minimum and maximum pan evaporation of the area is 2.8 and $5.5 \mathrm{~mm}$ per day, respectively.

Vanathavillu is a complex of Precambrian Basement dipped to the west overlain by Mannar sandstone beneath Miocene limestone (Lawrence and Dharmagunawardena 1981; Panabokke 2007). The limestone sequence narrows to the east overlain by the Moongil Aru formation as Quaternary sediments (about $40 \mathrm{~m}$ ). The available borehole data represent that the limestone aquifer thickness varies very much from one area to another (Water Resources Board, WRB). It was recorded that the limestone layer occurs at a depth of 54-60 $\mathrm{m}$ in the west of the area whereas the same is found at the depth of about $30 \mathrm{~m}$ in some middle parts. Additionally, it is found at the depth of relative $59 \mathrm{~m}$ in the southwest, while it is deeper to the north at around $73 \mathrm{~m}$ below surface. Two main aquifers dominate in the area including the Miocene limestone aquifer (deep confined and semi-confined aquifers) and Moongil Aru formation as overburden aquifer (one of the shallowest aquifer systems with lower permeability) (Davies and Herbert 1988). The overflowing artesian wells are observed in the coastal belt, western and northern zones of the basin, while some are encountered in the middle parts. GW flows from south to north in the limestone aquifer with increasing transmissivity northwards in the Kala Oya region, by which the aquifer is in artesian condition. The transmissivity increases from 500 to $1000 \mathrm{~m}^{2} /$ day along the trough and until some 2000 $\mathrm{m}^{2} /$ day northwards, particularly close to Kala Oya. Along the Moogil Aru formation, the transmissivity was recorded as lower than $30 \mathrm{~m}^{2} /$ day with water flow westwards then to the north (Lawrence and Dharmagunawardena 1981; Davies and Herbert 1988).
In terms of water quality, parts of Vanathavillu and toward Puttalam area are adversely affected due to high salinity in groundwater (notable western, northern, and central part). The Vanathavillu Basin has been deteriorated by high phosphate contamination concentration indicating more than permissible level, due to excessive use of agrochemicals and poor sanitation. Frankly, this salinity of groundwater generally derives from the dissolution of salts that may be precipitated in the soil via the brackish spray over the time, leaching of salts from salterns and the dissolution of minerals in the geological matrix (Edirisinghe et al. 2016).

\section{Kalpitiya area}

A low-lying area located in the Puttalam district of the north-western province of dry zone is between $7^{0} 59^{\prime}-8^{\circ} 8^{\prime}$ N-latitude and $79^{0} 41.5^{\prime}-79^{\circ} 45^{\prime}$ E-longitude. The area cover about $45 \mathrm{~km}^{2}$ with very flat area (0-10 mamsl) (Fig. 1b). In the area GW is used for domestic purposes and agriculture, and GW occurs in a shallow sandy aquifer underlain by limestone that has been known as a low-lying sand peninsula. The climate of the Kalpitiya area is characterized by high temperatures throughout the year, exceeding $27^{\circ} \mathrm{C}$, while annual rainfall is less than $1000 \mathrm{~mm}$ which is received mainly from October to December (Department of Census and Statistics 2016). Land cover is mostly occupied by agricultural lands, homesteads, and coconut lands, while scrublands and sand or beach cover a small area. Hydrogeologically, the boreholes availed by WRB shows that succession on the area consists of regosols overlying some 15-20 m of fine-coarse sands of marine origin. Moreover, beneath the sands are clays underlain by Miocene limestone, which has thickness of at least $20-30 \mathrm{~m}$ and is karstic in some areas (Jayasekera et al. 2008). The unconsolidated sand layer which supports the main freshwater source generally, varies from $8-16 \mathrm{~m}$, while the limestone aquifer is more saline. The sandy aquifer is more vulnerable to particularly nitrate and salinity due to intensive agricultural activities and households. The GW flow is from the middle of the peninsula to the east bounded by Puttalam lagoon and to the west bounded by Indian Ocean.

\section{Katana area}

This area falls within wet zone of western coast between latitudes $7^{0} 6^{\prime}-7^{\circ} 14^{\prime} \mathrm{N}$ and longitudes $79^{0} 51^{\prime}-79^{\circ} 54.5^{\prime}$ E with elevation of 0-25 mamsl, receiving a high average annual rainfall 1400 to $2600 \mathrm{~mm}$ and mean annual temperature $27.8{ }^{\circ} \mathrm{C}$ (Department of Census and Statistics 2012). The area is covered by an area of about $136 \mathrm{~km}^{2}$ with population of about 235,291 with the growth rate of 1.72 percent. Part of the area has been known as the Katunayake International Airport of the country and the Katunayake

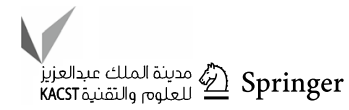


Export Processing Zone. Three main rivers exist in the area flowing from east to west across the area, namely Maha Oya in the north and Dandagan Oya and Kalu Oya in the south (Fig. 1c). The area is covered by built-up areas, homestead areas, coconut lands, paddy fields, water bodies and others. The coconut land covers majority of the area followed by homestead and paddy.

The inland area of Katana is formed by very old beach plain overlying interbedded clay and hard granite as bedrock. Small portion of laterite is found in the central west next to Negombo lagoon, from Negombo until Kandana crossing Ja-Ela and Seeduwa (Panabokke 2007). Available borehole data from WRB represent that the geological succession of the area composes of regosols and latosols of sands with significant clay (as alluvium soils) about 12-24 m thick resting on the hard rock.

Comparatively lower thickness is found in central eastern parts while deeper thickness in the central, western, and southern parts of the area. Additionally, the sand layer thickness seems to have high variation by varying from about 2-20 m underlain by interbedded clay layer varying from about 5-19 $\mathrm{m}$. The geological formation of the area has been hydrogeologically categorized as shallow (unconfined) aquifers and moderately deep aquifers (semi-unconfined), which are mainly composed of sand and sandy clay from 10 to $15 \mathrm{~m}$ thick underlain by confined clay layer overlying secondary aquifer (Gunawardena and Pabasara 2016). Sandy material is particularly observed along the coastline of Negombo lagoon, from the Ja-Ela in the south to Katunayake in the middle through Seeduwa in the central south of the area. The water level is estimated to be around 5-8 m below ground level (bgl) with flow direction from north to south and east to west and then discharge into Negombo lagoon at the west. A few parts of Katana area were found with saline intrusion toward Negombo lagoon. Compared to
Vanathalliu and Kalpitiya, nutrients and ionic concentrations in groundwater in the Katana are low.

\section{Data used and methodology}

\section{DRASTIC method}

The DRASTIC is an empirical method among other tools, which was devised for the US Environmental Protection Agency (USEPA) proposed by Aller et al. (1987). It was originally developed as an easy method in which the data can be always available and a user easily uses to test intrinsic GW vulnerability as the relative properties for GW contamination potential based on knowledge of hydrogeology. The method uses seven hydrogeological settings reflecting to DRASTIC acronym which is derived from Depth to water table, net Recharge, Aquifer media, Soil media, Topography, Impact of vadose zone, and hydraulic Conductivity (see Table 1). These parameters are then sub-divided into ranges or medium in which $\mathrm{D}, \mathrm{R}, \mathrm{T}$, and $\mathrm{C}$ belong to numerical ranges, while $\mathrm{A}, \mathrm{S}$, and $\mathrm{I}$ have been divided into media types. Each range or media is further assigned to various ratings from 1 to 10 , indicating the relative significance of each range or media with respect to their impacts on GW pollution potential, in contributing to aquifer vulnerability. The value of 1 and 10 denotes the little and greatest possibility for contamination, respectively. Each parameter is based on weighting factors varying between 1 (the least significant of contamination potential) and 5 (the most significant of contamination potential). The DRASTIC is developed to provide an assessment tool for relative vulnerability based on three main presumptions (1) all contaminants are introduced at the land surface; (2) the movement and transportation of the contaminants to GW depends on precipitation; (3) there

Table 1 The parameters of DRASTIC method (Aller et al. 1987)

\begin{tabular}{|c|c|c|c|}
\hline Parameter & Description & $\begin{array}{l}\text { Relative } \\
\text { weight }\end{array}$ & Rating \\
\hline Depth to water (D) & $\begin{array}{l}\text { The distance from the ground surface to the water table, deeper water table levels imply lesser } \\
\text { chance for contamination to occur }\end{array}$ & 5 & $1-10$ \\
\hline Net recharge $(\mathrm{R})$ & $\begin{array}{l}\text { The amount of water which penetrates the ground surface and reaches the water table, recharge } \\
\text { represents for the vehicle transporting pollutants }\end{array}$ & 4 & $1-9$ \\
\hline Aquifer media (A) & The saturated zone material properties, which controls pollutant attenuation processes & 3 & $1-10$ \\
\hline Soil media $(\mathrm{S})$ & $\begin{array}{l}\text { The uppermost weathered portion of the unsaturated zone and controls the recharge amount that } \\
\text { can infiltrate downward }\end{array}$ & 2 & $1-10$ \\
\hline Topography (T) (Slope) & $\begin{array}{l}\text { The slope of the land surface, it denotes whether the runoff will remain on the surface to allow } \\
\text { contaminant percolation to the saturated zone }\end{array}$ & 1 & $1-10$ \\
\hline $\begin{array}{l}\text { Impact of vadose } \\
\text { zone(unsaturated zone) } \\
\text { (I) }\end{array}$ & $\begin{array}{l}\text { The unsaturated zone material, it controls the passage and attenuation of the contaminated mate- } \\
\text { rial to the saturated zone }\end{array}$ & 5 & $1-10$ \\
\hline Hydraulic conductivity (C) & $\begin{array}{l}\text { The aquifer ability to transmit water, hence determines the flow rate of contaminant material } \\
\text { within the GW system }\end{array}$ & 3 & $1-10$ \\
\hline
\end{tabular}


Table 2 Ratings of the DRASTIC parameters of the study areas with the assigned weight of $1-5$

\begin{tabular}{|c|c|c|c|c|c|}
\hline \multicolumn{2}{|c|}{ Vanathavillu } & \multicolumn{2}{|c|}{ Kalpitiya } & \multicolumn{2}{|l|}{ Katana } \\
\hline Parameter & Rating & $\begin{array}{l}\text { Param- } \\
\text { eter }\end{array}$ & Rating & $\begin{array}{l}\text { Param- } \\
\text { eter }\end{array}$ & Rating \\
\hline $\mathrm{D}$ & $1-10$ & $\mathrm{D}$ & $7-10$ & $\mathrm{D}$ & $5-10$ \\
\hline $\mathrm{R}$ & 3 and 6 & $\mathrm{R}$ & 3 and 6 & $\mathrm{R}$ & 9 \\
\hline A & 7 and 9 & A & 8 & A & 8 \\
\hline S & $\begin{array}{r}3,5,6 \\
\text { and } 9\end{array}$ & $S$ & 9 & $S$ & 6 \\
\hline $\mathrm{T}$ & $\begin{array}{l}3,5,9 \\
\text { and } 10\end{array}$ & $\mathrm{~T}$ & $\begin{array}{c}5,9 \text { and } \\
10\end{array}$ & $\mathrm{~T}$ & 5,9 and 10 \\
\hline I & 6 & I & 8 & I & 6 \\
\hline $\mathrm{C}$ & $1-10$ & $\mathrm{C}$ & $4-10$ & $\mathrm{C}$ & $1-4$ \\
\hline
\end{tabular}

Table 3 DRASTIC index ranges for qualitative vulnerability categories (Lobo-Ferreira and Olivereira 2004)

\begin{tabular}{lllll}
\hline \multicolumn{4}{l}{ DRASTIC qualitative category } & \\
\hline & Low & Moderate & High & Very high \\
\hline DIVI & $<120$ & $120-159$ & $160-199$ & $>199$ \\
\hline
\end{tabular}

is no consideration on the depth to water to the regional aquifer and perched zones.

There are deviations of the ranges and ratings of the area from the expert assignments given in DRASTIC standards. Thus, modification for typical ranges and ratings were made according to local hydrogeological conditions (see Table 2). These modifications depend on the specific regional data at Vanathvillu, Kalpitiya and Katana areas. The modified ranges and ratings have been employed to determine the local DRASTIC index, showing different levels of GW vulnerability of the areas. The intrinsic GW vulnerability is the numerical overall grade of vulnerability written as DRASTIC Intrinsic Vulnerability Index (DIVI), which is calculated from the summation of the product of ratings and weights of the seven variables and is formulated in Eq. (1).

$$
\begin{aligned}
\text { DIVI }= & \sum_{i=1}^{7} \mathrm{~W}_{i} * \mathrm{R}_{i}=\mathrm{D}_{r} \mathrm{D}_{w}+\mathrm{R}_{r} \mathrm{R}_{w}+\mathrm{A}_{r} \mathrm{~A}_{w}+\mathrm{S}_{r} \mathrm{~S}_{w} \\
& +\mathrm{T}_{r} \mathrm{~T}_{w}+\mathrm{I}_{r} \mathrm{I}_{w}+\mathrm{C}_{r} \mathrm{C}_{w}
\end{aligned}
$$

where $\mathrm{D}, \mathrm{R}, \mathrm{A}, \mathrm{S}, \mathrm{T}, \mathrm{I}$, and $\mathrm{C}$ refer to respective factors of the DRASTIC and the subscripts " $r$ " and " $w$ " indicate rating and weight factor, respectively. The high values of DIVI indicate greater pollution potential of GW to the contamination or high aquifer vulnerability. Since original DRASTIC method has no classification of vulnerability, the computed DIVIs were converted into qualitative vulnerability classifications of low, moderate, high, and very high (Lobo-Ferreira and
Olivereira 2004) (see Table 3) and based on histogram of vulnerability index as low, moderate, and high proposed by Kumar et al. (2017). Beneficial GIS environment was used to derive the vulnerability maps by overlaying various spatially referenced digital data layers. It has high capacity to collect, store, display, and process (i.e., geo-referencing, spatial analysis) various types of data and quickly the parameters employed to categorize GW vulnerability.

\section{Sensitivity analysis}

Until now, the criticism and argument still happen to the DRASTIC method. The limitation of the fundamental DRASTIC has been found to ignore one of main factors as anthropogenic parameter, which influences accuracy and suitability of expressed severity of vulnerability (Kumar et al. 2017). The anthropogenic and agricultural activities are responsible for deterioration of groundwater level and increasing vulnerability. To meet their demands, man has been utilizing land-use for year, the land-use has greatly been changed due to various dynamic developments, urbanization, population growth, and other interferences (Panagopoulos et al. 2006; Zhang et al. 2015; Kumar et al. 2017). The study areas located in Northwestern and Western regions of Sri Lanka have been found remarkable changes in land-uses due to human activities, particularly agricultural activities, and some industrial developments, which is consequence of quick urbanization, land-use expansion, and demographic growth for past few decades. Based on the census of 2016, it was estimated that much population has increased with density from about 518 to over 2700 persons per sq. $\mathrm{km}$ and with growth rate of $0.5-1.7$ percent (Annual Performance Report and Accounts 2016; Department of Census and Statistics 2016). For this reason, the study is implemented to modify the DRASTIC method with an inclusive factor as the anthropogenic parameter (e.g., landuse and land cover). Hence, in order to eliminate all these doubts, sensitivity analysis of the model and modification are carried out.

The sensitivity analysis as an advanced technique operated to check its adaptability of each parameter between map layers to local conditions in the research areas. Subjectivity can thus be reduced to increase reliability. Map removal sensitivity and single-parameter sensitivity analysis were used for this study. The map removal sensitivity analysis, on one hand, is performed to find out the most influenced and sensible factor of vulnerability map, which is operated through GIS by reducing weight of one (or more) parameter assigned by the DRASTIC to minimum value of 1 , each at a time while retaining the ratings of the parameters (Lodwick et al. 1990; Mato 2002; Babiker et al. 2005). New DIVIs is reclassified as summarized in Table 4. On the other hand, the single-parameter sensitivity analysis is to calculate the 
Table 4 DIVIs by changing each of the seven DRASTIC parameters to minimum weight of 1

\begin{tabular}{|c|c|c|c|c|c|c|c|c|}
\hline \multicolumn{2}{|c|}{ Parameters changed } & D & $\mathrm{R}$ & A & S & $\mathrm{T}$ & I & C \\
\hline \multicolumn{9}{|c|}{ Vanathavillu area } \\
\hline \multirow[t]{4}{*}{ Index } & Min & 86 & 80 & 79 & 92 & 97 & 73 & 95 \\
\hline & Mean & 103.1 & 105.3 & 104.2 & 115.7 & 121 & 97 & 119 \\
\hline & $\operatorname{Max}$ & 117 & 137.8 & 142 & 149 & 156 & 132 & 154 \\
\hline & SD & 6.3 & 7.4 & 8.3 & 8.2 & 8.4 & 8.4 & 8.4 \\
\hline \multicolumn{9}{|c|}{ Kalpitiya area } \\
\hline \multirow[t]{4}{*}{ Index } & Min & 124 & 149 & 144 & 151 & 160 & 128 & 147 \\
\hline & Mean & 142.6 & 163.2 & 162.1 & 169.1 & 178.1 & 146.1 & 163.4 \\
\hline & Max & 156 & 177.9 & 180 & 187 & 196 & 164 & 175.9 \\
\hline & SD & 7.2 & 5.4 & 7.9 & 7.9 & 7.9 & 7.9 & 6.9 \\
\hline \multicolumn{9}{|c|}{ Katana area } \\
\hline \multirow[t]{4}{*}{ Index } & Min & 120 & 116 & 127 & 137 & 143 & 119 & 139 \\
\hline & Mean & 126.9 & 136.3 & 147.3 & 157.3 & 163.3 & 139.3 & 159.2 \\
\hline & $\operatorname{Max}$ & 134 & 147 & 158 & 168 & 174 & 150 & 166 \\
\hline & SD & 1.1 & 2.7 & 2.7 & 2.7 & 2.7 & 2.7 & 2.6 \\
\hline
\end{tabular}

effective (actual) weights of each parameter used to compare with the theoretical weights utilized in calculation of DIVIs. This is to test the impact of an individual parameter on the pollution potential based on local condition of the research area (Napolitano and Fabbri 1996) based on Eq. (2) with the analysis information in form of statistical summary (see Table 5)

$W=\left(P_{r} P_{w} / V\right) \times 100$
Table 5 Statistics of the singleparameter sensitivity analysis

\begin{tabular}{|c|c|c|c|c|c|c|c|}
\hline \multirow[t]{2}{*}{ Parameter } & \multirow{2}{*}{$\begin{array}{l}\text { Theoretical } \\
\text { weight }\end{array}$} & \multirow{2}{*}{$\begin{array}{l}\text { Theoretical } \\
\text { weight (\%) }\end{array}$} & \multicolumn{4}{|c|}{ Effective weight (\%) } & \multirow{2}{*}{$\begin{array}{l}\text { Calcu- } \\
\text { lated } \\
\text { weight }\end{array}$} \\
\hline & & & Min & Mean & Max & SD & \\
\hline \multicolumn{8}{|c|}{ Vanathavillu area } \\
\hline $\mathrm{D}$ & 5 & 21.7 & 4.4 & 18.3 & 38 & 5.1 & 4.2 \\
\hline $\mathrm{R}$ & 4 & 17.4 & 8.7 & 14.3 & 24.5 & 4.1 & 3.3 \\
\hline A & 3 & 13 & 13.5 & 20.8 & 27.8 & 2.6 & 4.8 \\
\hline S & 2 & 8.7 & 4.4 & 8.7 & 15.5 & 1.5 & 2 \\
\hline $\mathrm{T}$ & 1 & 4.3 & 2.6 & 7.6 & 9.9 & 1 & 1.7 \\
\hline I & 5 & 21.7 & 19.2 & 24.9 & 30.9 & 1.7 & 5.7 \\
\hline $\mathrm{C}$ & 3 & 13 & 1.9 & 2.5 & 3.1 & 0.2 & 0.6 \\
\hline \multicolumn{8}{|c|}{ Kalpitiya area } \\
\hline $\mathrm{D}$ & 5 & 21.7 & 19.4 & 24.9 & 28.3 & 1.5 & 5.7 \\
\hline $\mathrm{R}$ & 4 & 17.4 & 6.7 & 11 & 14.4 & 2.9 & 2.5 \\
\hline A & 3 & 13 & 12.2 & 13.5 & 15 & 0.6 & 3.1 \\
\hline S & 2 & 8.7 & 9.2 & 10.1 & 11.3 & 0.5 & 2.3 \\
\hline $\mathrm{T}$ & 1 & 4.3 & 2.6 & 5.6 & 6.2 & 0.3 & 1.3 \\
\hline I & 5 & 21.7 & 20.4 & 22.5 & 25 & 1 & 5.2 \\
\hline $\mathrm{C}$ & 3 & 13 & 6.7 & 12.3 & 17.3 & 2.4 & 2.9 \\
\hline \multicolumn{8}{|c|}{ Katana area } \\
\hline $\mathrm{D}$ & 5 & 21.7 & 16.3 & 27.9 & 31.5 & 1.2 & 6.4 \\
\hline $\mathrm{R}$ & 4 & 17.4 & 20.7 & 22 & 25.2 & 0.4 & 5.1 \\
\hline A & 3 & 13 & 13.8 & 14.7 & 16.8 & 0.3 & 3.4 \\
\hline S & 2 & 8.7 & 6.9 & 7.4 & 8.4 & 0.1 & 1.7 \\
\hline $\mathrm{T}$ & 1 & 4.3 & 3.1 & 6 & 7 & 0.4 & 1.4 \\
\hline I & 5 & 21.7 & 17.2 & 18.4 & 21 & 0.3 & 4.2 \\
\hline $\mathrm{C}$ & 3 & 13 & 1.8 & 3.7 & 7.4 & 0.5 & 0.8 \\
\hline
\end{tabular}


where $W$ is the "effective" weight of each parameter, $P_{r}$ and $P_{w}$ are the rating value and weight of each parameter, and $V$ is the overall intrinsic vulnerability index. The effective weights are dependent on the single parameter value with reference to the rest of six parameters and also to each weight allocated by DRASTIC analysis (Neshat and Pradhan 2017). The resulted single-parameter sensitivity analysis was compared with the theoretical weights, so that the most effective factors contributing to the vulnerability index can be determined. Modification on the assigned weights of DRASTIC method to minimize the subjectivity and to fit to the local conditions is useful for further research.

The risk of GW contamination is dependent on both intrinsic vulnerability and contaminant load imposed by human activities based on various land-use potential. It is possible that the area has high vulnerability but no pollution risk, due to the absence of significant contaminant load (no significant land-use activities).

To evaluate GW risk to the actual areas, integrated (specific) GW vulnerability maps were made through modifying the DRASTIC method as involving an additional parameter reflecting anthropogenic impact. Land-use (LU) which provides diverse degrees of contaminant load is chosen as the additional parameter. Each LU category was assigned rating $\left(\mathrm{LU}_{r}\right)$ (see Table 6) based on the significance of each class in pollution potential by applying the highest weight $\left(\mathrm{LU}_{w}\right)$ of 5 (modified from Al-Adamat et al. 2003; Farjad et al. 2012). The combination of this parameter with DIVI through linear addition was utilized to determine the specific vulnerability index. Therefore, the DRASTIC Specific Vulnerability Index (DSVI) is calculated according to expression in Eq. (3).

$\mathrm{DSVI}=\mathrm{DIVI}+\mathrm{LU}_{r} \times \mathrm{LU}_{w}$

To test the accuracy and adaptation of the reality to actual area of GW risk, the validation of DSVI map was performed. The nitrate was chosen as the validation parameter since it is a common initial contaminant and is a good indicator of GW quality deterioration. The monitoring of nitrate concentration of the areas was Carried out by sampling water from 71 wells among which 11 samples were from the Vanathavillu area (during November 2017), 34 samples were from the Kalpitiya (during January 2018), and 26 samples were from the Katana (during July 2018). It is well noted that the samples were taken as one-time sampling, which unfortunately indicates that no temporal variation of the observations was made and considered for the study. The contents of nitrate were analyzed using standard method $\mathrm{HACH}$ DR/2010 spectrophotometer.

\section{Results and discussion}

\section{Application of the DRASTIC model to the study areas}

All the DRASTIC factors were evaluated for GW vulnerability by using the available hydrogeological data. The weights and ratings were adopted as specified in the predetermined generic weight and typical rating of the original DRASTIC scheme, respectively, with respect to the others in order to determine the relative significance of it. Figure 2 indicates examples of the quantitative results of the rated layer maps of DRASTIC parameters in Vanathavillu to gain the DRASTIC intrinsic vulnerability maps of the three study areas.

The ranges of depth to water table were determined based on the obtained 60 borehole data (WRB dataset) combined with direct field measurements from dug-wells. The inverse distance weighted (IDW) technique within GIS was performed to interpolate the data. The aquifer of Vanathavillu is shallow to relative depth $(0-45 \mathrm{~m})$, lowering to the east next to the Puttalam lagoon, with rating scores from 1 to 10 . It is relatively deeper compared to the shallow aquifer in the Kalpitiya varying from 0 to about $6 \mathrm{~m}(1.55 \mathrm{~m}$ over most of the area) with the rating 7 to 10 , and in Katana $0-15 \mathrm{~m}$ rated 5-10, showing $1.5-5 \mathrm{~m}$ over most of the area with decreasing to the south. A greater chance for attenuation occurs as the depth to water rises and therefore results in a longer travel time as residence time for any potential contaminant and vice versa (Aller et al. 1987). The lower (or overflowing) the groundwater, the bigger the rating score. The assigned rating of 10 denotes the most significant to vulnerability to pollution potential, while 1 indicates the least significant.

The recharge is main vehicle for leaching and transporting contaminant to water table. Both higher and lower recharge rates are mainly attached with soil types, soil characteristics, vadose zone thickness and materials, amount of rainfall, infiltration rate, and evapotranspiration which influence on recharge and contamination potential
Table 6 Ratings of the land-use layer with the highest assigned weight of 5

\begin{tabular}{|c|c|c|c|c|c|}
\hline \multicolumn{2}{|l|}{ Vanathavillu } & \multicolumn{2}{|l|}{ Kalpitiya } & \multicolumn{2}{|l|}{ Katana } \\
\hline Land-use & Rating & Land-use & Rating & Land-use & Rating \\
\hline Coconut, paddy & 9 & Vegetable & 10 & Coconuts, Paddy & 9 \\
\hline Settlements & 8 & Coconut & 9 & Built-up area, Homestead & 8 \\
\hline Forest, other & 2 & Non-agricultural area & 7 & Other & 2 \\
\hline Sand/beach, water bodies & 1 & Beach and dunes & 1 & Water body & 1 \\
\hline
\end{tabular}



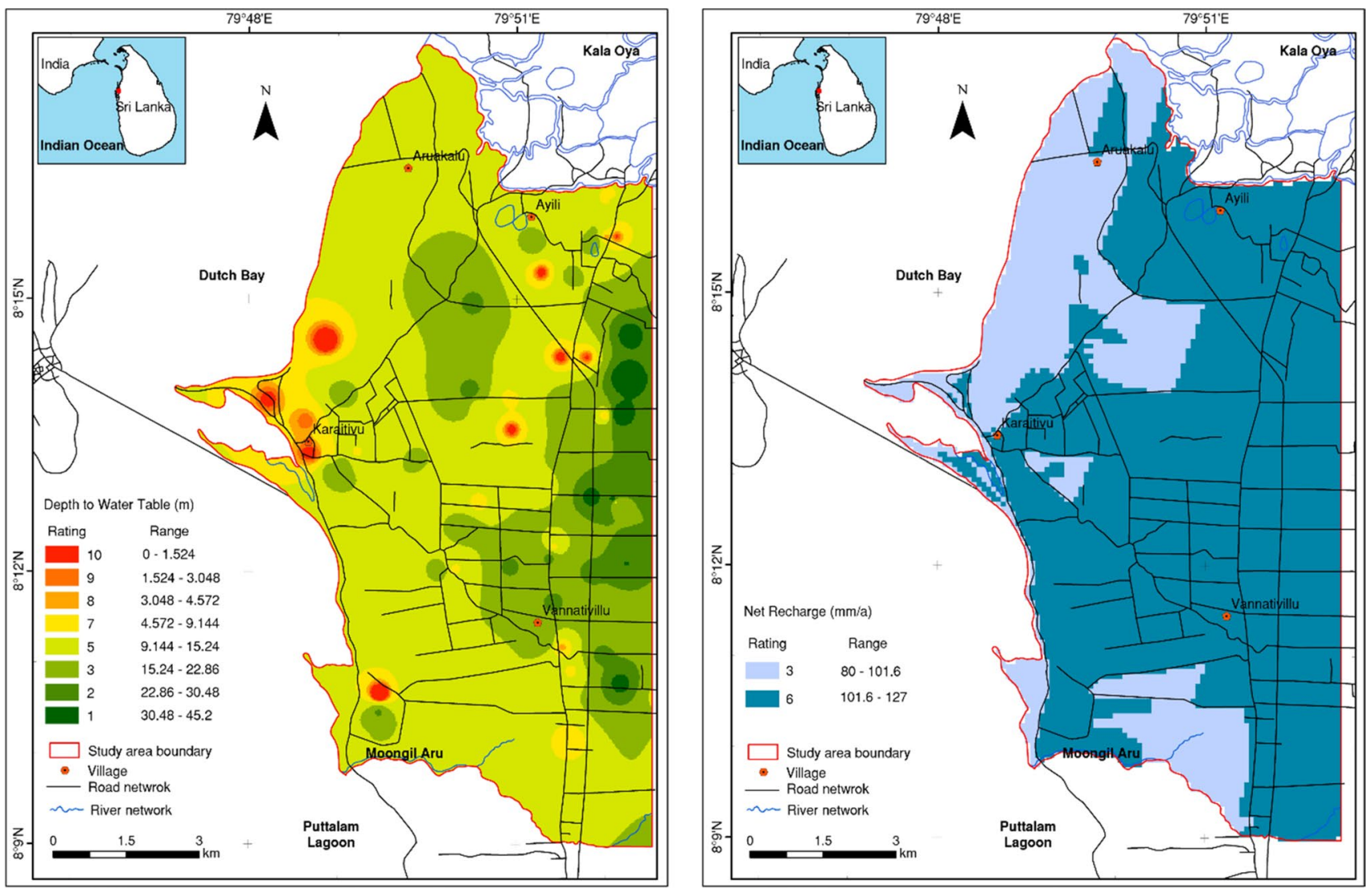

Fig. 2 Examples of the rated maps of Vanathavillu used to compute the DRASTIC vulnerability index. The rating score 1 expresses a little possibility for contamination, while the score 10 shows the greatest possibility

(Aller et al. 1987). The main components incorporated in the recharge feature for the areas are rainfall and losses due to evapotranspiration and runoff. No precise data, however, were available for the net recharge, and thus only estimated values were used, and the recharge was calculated employing a simple water balance method. Since the study area is located in the tropical humid area, groundwater recharge estimation in the area is based on the rainfall recharge of natural factor, soil type, and land-use conditions due to different conditions of development (land cover, land-use pattern distribution, density of population, formal-informal settlement, on site sanitary system, etc.). The recharge rate would actually vary in time and condition (Putra 2007). To estimate this rainfall recharge, simple resulting water balance relationship (Lerner 2002; Putra 2007) is expressed in Eq. (4).

$R=P-\mathrm{ET}_{r}-\mathrm{Ro}$

where $R$ is groundwater recharge rate ( $\mathrm{mm} /$ year), $P$ refers to rainfall (mm/year), $\mathrm{ET}_{r}$ represents real/effective evapotranspiration (mm/year), and Ro indicates runoff with assumption of natural-rural condition (mm/year). The 2008-2015 rainfall data received from Department of Census and Statistics (2016) were interpolated by using IDW technique to determine rainfall distribution over the areas. The effective evapotranspiration of the areas was calculated using empirical formula proposed by Turc (1954) as the formula is with relation of the precipitation and mean temperature of the areas. The runoff of the areas was estimated by the SCSCN method (Soil Conservation Services Curve Number) originally developed by the United States Department of Agriculture (USDA) (SCS 1986) concerning with soil types, land-use covers, and surface conditions. Unfortunately, full detailed steps of evapotranspiration and runoff could not be mentioned here. Ultimately, the estimated annual net recharge of each area was thus computed and taken as medium recharge varies between 80 and $127 \mathrm{~mm} / \mathrm{a}$ in Vanathavillu and 73-124 mm/a in the Kalpitiya, rated score from 3 to 6 based DRASTIC assumptions. High recharge was found in the Katana, which is 500 to $800 \mathrm{~mm} / \mathrm{a}$, with an absolute rating score of 9 . Normally, the greater the recharge, the greater the potential for groundwater pollution, but depending on soil characteristics.

The aquifer media affects the flow within aquifer which controls the rate of contaminant contact within the aquifer 
media, which produces the degree of attenuation (Sener et al. 2009). The data related to the aquifer media have been received and identified from the available well log data (WRB), surface geological map and lithologic cross-sections of the study areas. The aquifer types availed in Vanathavillu were categorized into sand and gravel with small amount of clay (unconfined) (rating 7) and limestone (confined) in which the limestone is the main aquifer and majorly distributed and rated as 9. The limestone is considered here due to its upward seepage that may affect the water table of the area. The shallow unconfined sandy aquifer was identified in the Kalpitiya, while adversely moderately deep unconfined aquifer in the Katana was also estimated as sand and was assigned high rating of 8 . Medium with higher grain size and permeability allows faster movement of water and pollutants, and thus, has a higher rating score, which highly contributes to pollution potential.

The soil is the important zone in which surface pollutants moving downward are attenuated and reduced at deeper depth in the underlying areas through absorption, dispersion, ionic exchange, oxidation, biodegradation, etc. (Babiker et al. 2005). The soil distributions of the study areas were grouped based on soil maps of the areas obtained from Survey Department of Sri Lanka. Vanathavillu is mainly dominated by red earth soil deposit (sand, silt, and clay) with assigned rating 6, while the sandy (rating 8) and alluvium sand (rating 6) dominance has been observed in the Kalpitiya and Katana, respectively. Suitable rating values were assigned to each soil type per DRASTIC standard with reference to Soil of Ceylon (Moormann and Panabokke 1961). The higher the ratings, the greater the contribution to vulnerability to contamination.

The topography affects infiltration, percolation, and contaminant migration. Regions of consistently low topography are vulnerable as water can pool and infiltrate into the subsurface. This is particularly vital in activities such as application of fertilizers, pesticides, and herbicides, where the effect of the contaminant tends to be cumulative (Sener et al. 2009). The slope variation percentages of the research areas were estimated from the Digital Elevation Model (DEM). Compared to the DRASTIC scheme, the study areas are generally relatively flat less than $2 \%$ (low steepness). The slope ranges from 0 to about $14 \%$ at Vanathavillu, $0-7 \%$ at the Kalpitiya, and $0-10 \%$ at the Katana. The lower slope, especially $<2 \%$, was hence assigned the higher rating (10), and more contamination potential infiltration or higher vulnerability of groundwater occurrence can be expected.

The impact of vadose zone mostly consists of unconsolidated materials that controls the amount, path length and period of time of recharge associated with the contaminants based on the material thickness and characteristics. The vadose zone identification of the study areas is based on the borehole log recorded by WRB and surface geological map from Cooray (1982). Sand with significant clay and silt was sorted in Vanathavillu and Katana with rating score of 6, while sandy media with the high rating (8) belongs to the Kalpitiya. The higher permeable and less thickness contributes to greater vulnerability to contamination and vice versa.

The hydraulic conductivity plays an important role in pollutant migration rate and dispersion (Aller et al. 1987). This study considers only unconfined overburden aquifer, which experiences contaminant before reaching to underlying confined aquifer, as is valid from the DRASTIC. The hydraulic conductivity, $\mathrm{K}$ ( $\mathrm{m} /$ day), of Vanathavillu ranges from 0.003 to $0.60 \mathrm{~m} /$ day rated as an absolute value (1) (lowest vulnerability potential) as similar value throughout the area due to composing of mixed sand, clay, and silt, which was extracted from the published report of Lawrence and Dharmagunawardena (1981). This value is smaller compared to the DRASTIC ranges and ratings. Hence, this naturally has greater chance for dispersion and degradation to reduce contamination concentration. The hydraulic conductivities of the Kalpitiya and Katana were calculated from relationship: $K=T / b$, where $T$ is transmissivity of the aquifer $\left(\mathrm{m}^{2} /\right.$ day) determined from several pumping test data recorded by National Water Supply and Drainage Board (NWSDB), applying Cooper-Jacob method (Fetter 2001), and b is aquifer thickness (m) estimated from the borehole log of WRB. The resulted hydraulic conductivities were classified based on the DRASTIC framework into four classes in the Kalpitiya (17-28.6, 28.6-40.8, 40.8-81.6, and 81.6-108.8, m/ day with respective rating scores of $4,6,8$ and 10) and three class in the Katana (2-4.1, 4.1-12.2, and 12.2-13.5, m/day with the rating 1, 2 and 4). Notably, all the values are just obtained as estimated values. The higher $\mathrm{K}$ values of the Kalpitiya highly contributed to the vulnerability index.

\section{Groundwater vulnerability and risk assessments}

The thematic layers of the seven DRASTIC factors were combined in a single chart to develop a GW vulnerability maps to visualize the areas which are more vulnerable to pollution than the others. These factors have been implemented as raster format with a regular grid of $25 \times 25$ resolution as map layers within ArcView GIS 10.1. The operation of vulnerability indices was worked out by map overlays and classification in the spatial analysis applying appropriate GIS overlay functions as weighted sum based on the DRASTIC formula. The result is ultimately given as a numerical value. The notable appearance classification from the DRASTIC maps shows that the index varies from less than 120 to 196 . These values are classified based on the basis of the interval of vulnerability index made by LoboFerreira and Olivereira (2004) and complies within the range of $<120$ to $>199$, noted as low $(<120)$, moderate $(120-159)$, high (160-199), and very high (>199). These classes and

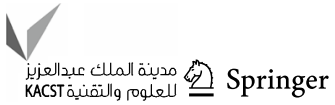


vulnerability indices indicate similar histogram of vulnerability index created by Kumar et al. (2017), with small exception of different interval number. However, it should be inferred that the results of the study are quite reasonable. Groundwater of the studied areas is thus under vulnerable to contamination from low to high level (Fig. 3). The higher index indicates the greater pollution potential.

Two levels of groundwater vulnerability potential at Vanathavillu indicates as low (index $<120$ ) and moderate (120-156). The deeper groundwater table and less permeable soils make the groundwater of this area to be within low to moderate vulnerability. About half of the area falls within moderate vulnerable zone distributed from south to north as particularly found at western (especially in Karaitivu village), central, southwestern, and northern areas close to Kala Oya river. This is followed by the few isolated spots at the east and north-west of the area (Fig. 3a). This may be due to lower depth to water table, possible water seepage downward from underlying Vanathavillu limestone (Lawrence and Dharmagunawardena 1981), and gentle slope permitting higher contamination infiltration. One should bear in mind that the DRASTIC indices are relative values, and a zone where a low index class does not significantly mean that it is from contamination, but has relative less contamination susceptibility compared to the areas with high DRASTIC indices. Morris et al. (2003) claim that a high vulnerability indicates that the land is susceptible to several pollutants besides those which can be heavily absorbed and can be easily transformed, whereas low vulnerability category only refers to susceptibility of the most unending pollutants in the longer period. The low vulnerable regions can make groundwater have high hazard once significant anthropogenic activities exist. Further, it is noted from the DIVI map that the Kalpitiya falls under high vulnerability of groundwater to contamination (red zone) with index 160-196 propagated throughout the area (Fig. 3b). This means that the intrinsic (natural) hydrogeological characteristics of the area indicate that they have a high susceptibility to pollution. There is possibility for having high vulnerability but less or no pollution risk, due to the absence of a significant contaminant load. The very shallow groundwater table $(<5 \mathrm{~m})$, higher permeable material (sandy soil), and very flat slope $(<2 \%$, increasing infiltration and hence less travel time to reach the water table) possibly make the Kalpitiya aquifer highly vulnerable. The DIVI map also clearly displays that groundwater vulnerability in the Katana ranges from moderate (143-159) to high (160-174) potential, in which the dominance of moderate susceptibility distributes throughout the area from south to north located in Ja-Ela, Seeduwa, Katunayake and Kochchikade, whereas high degree of pollution susceptibility is mainly found at some areas of the south and central south with several isolated spots at the central east and central north-west (Fig. 3c). The areas under high vulnerability are caused by the shallowest depth to water table $(<1.5 \mathrm{~m})$, higher recharge rate, permeable sand soil, and flat slope. The marshy soil with less permeable properties (in the north-east, east and north) and increasing groundwater table depth and slope percentage may contribute to the moderate vulnerability.

The sensitivty analysis performed with the DRASTIC method has been believed as an advanced technique to check the adaptability of each parameter between map layers to local conditions in the areas. As displayed in Tables 4 and 5 , of the seven factors tested, vadose zone, depth to water, aquifer media, topography followed by soil media tend to be the most sensitive parameters in the DRASTIC model to fit local conditions in Vanathavillu, while the others show less effectiveness. This is because of the evidence that the lowest partial index values after weights changed and that their effective weights are higher than their theoretical weights after single-parameter analysis. This is also because of the parameters with the highest fixed pre-assigned weight of 5 . Further notation from Tables 4 and 5 also reveals that depth to water, vadose zone, topography followed by soil media and aquifer media of the Kalpitiya area are the most influencial parameters in assessing groundwater vulnerability. For the Katana, it has been seen that the depth to water and net recharge followed by vadose zone, aquifer media and topography seem to be the most effective factors influencing the groundwater vulnerability of the area.

The integrated (specific) vulnerability maps through linear combination between intrinsic vulnerability maps and land-use rating map demonstrate that groundwater of the areas under study ranges from very low to high risk. The very low to moderate contamination risk was found in the Vanathavillu area (Fig. 4a), in which the moderately pollution risks (about 13\%) are particularly marked in central, wester and southwester parts of the area. The moderate pollution risk was also found at isolated spots in north, south, central east and southwest, central north-east and central north-west of the area. This is mainly because of the higher contamination loading associated with coconut cultivation and settlements. Even though the DRASTIC map particularly showed that the south and north part was moderate vulnerable in terms of natural factors, pollution risk was very low. This is due to no land-use activities as the area is mostly dominated by forest lands. It was implied that no contamination risk is anticipated from land-uses other than coconut fields and settlement areas in Vanthavillu. High and moderate pollution risk zones were identified in the Kalpitiya in which the higher risk of contamination is acountable to about $82 \%$ due to dense agricultures (especially vegetables) with excessive fertilizer applications and high homesteads (improper sanitation which facilitates more infiltration into shallow aquifers). A similar result was also evidenced by Jayasingha et al. (2011) and Jayasingha et al. (2015). 


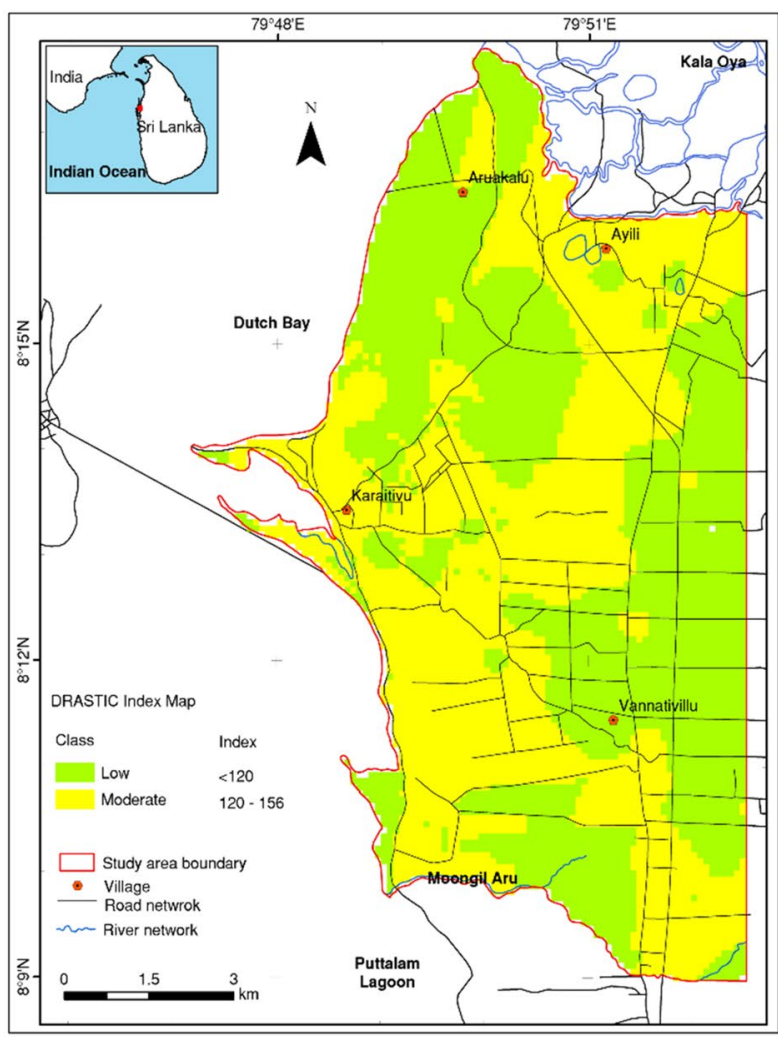

(a)

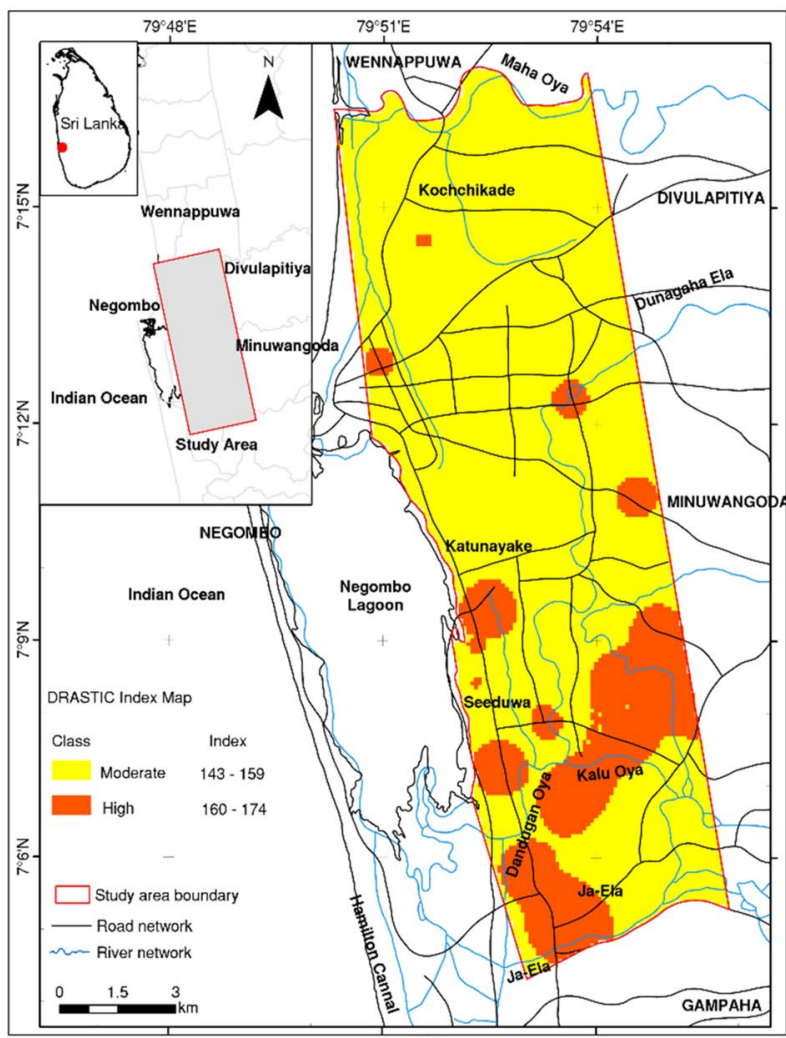

(c)

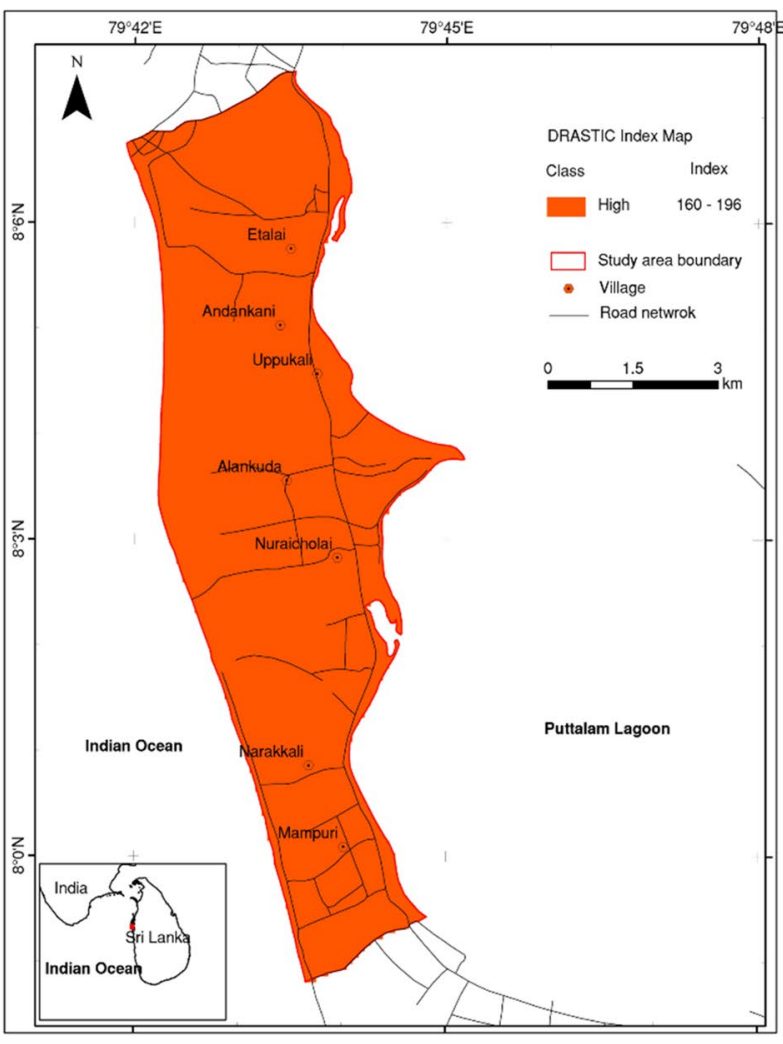

(b)

Fig. 3 Intrinsic vulnerability maps of the a Vanathavillu, b Kalpitiya, and $\mathbf{c}$ Katana 


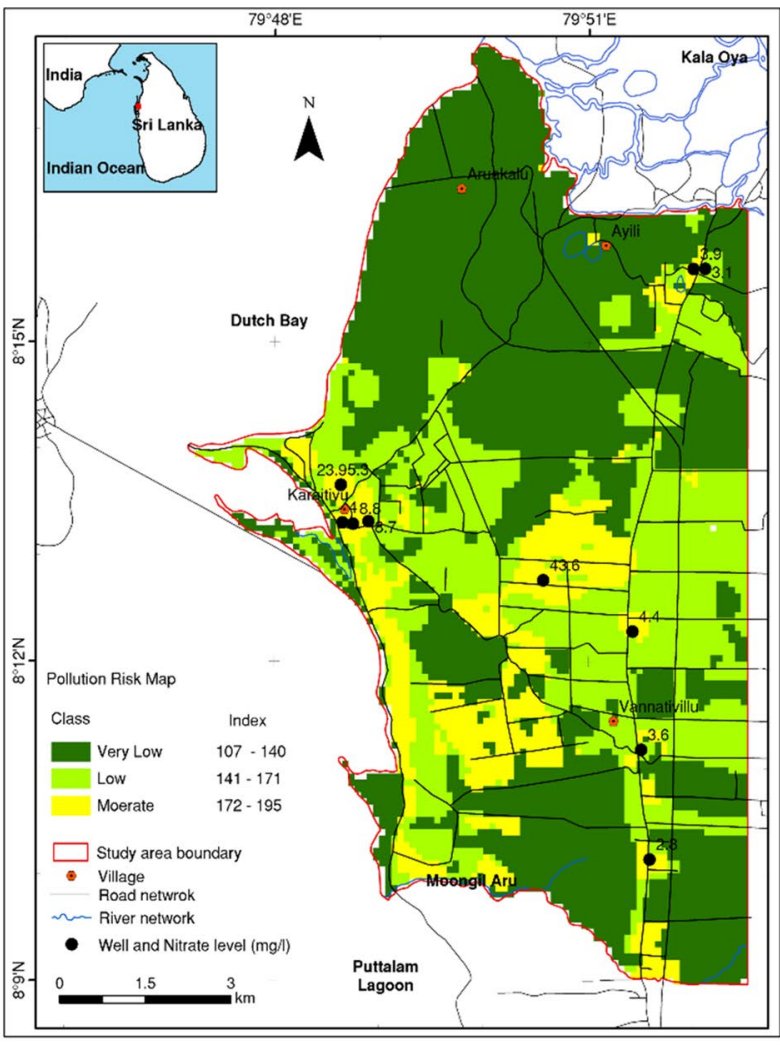

(a)

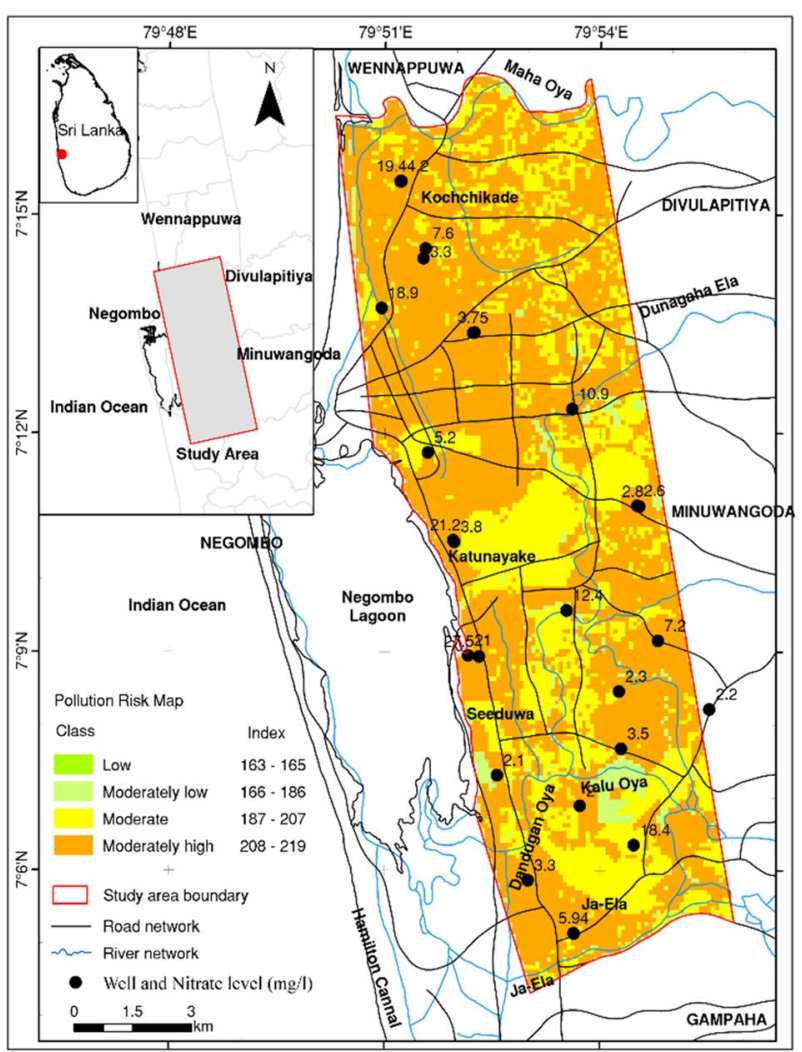

(c)

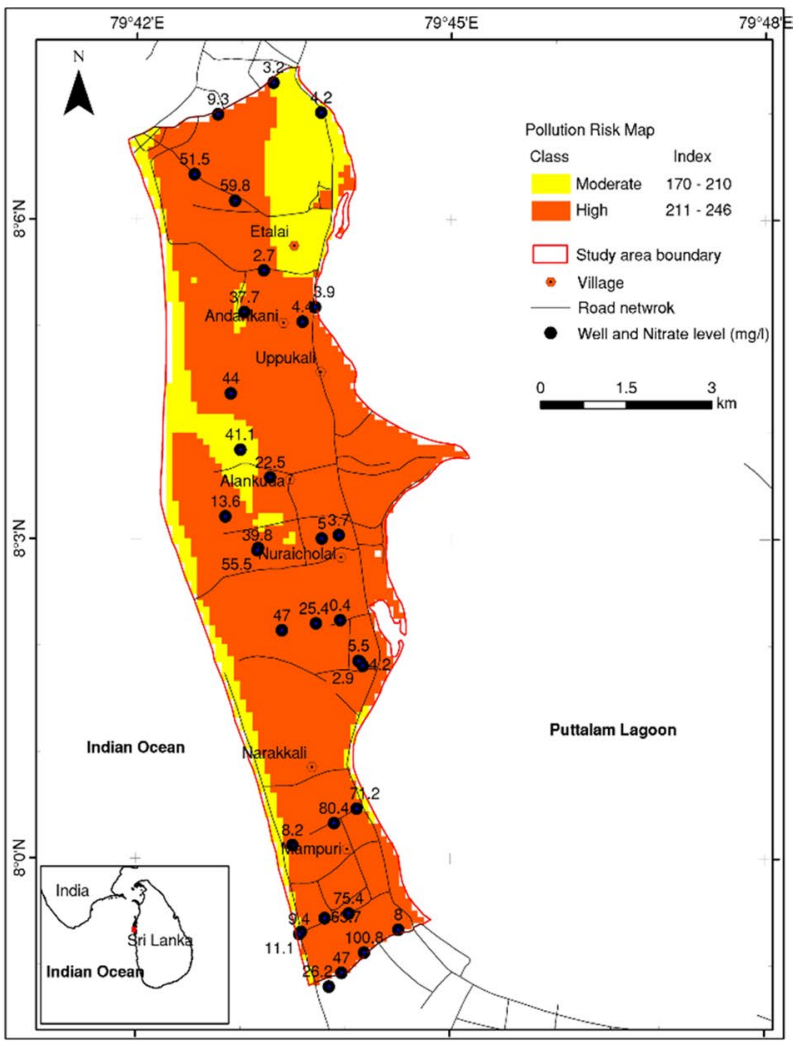

(b) 
४Fig. 4 Integrated vulnerability map combining the intrinsic vulnerability with the potential pollution sources based on land-use categories in the a Vanathavillu, b Kalpitiya, and c Katana

The elevated use of fertilizer and groundwater for irrigation can enable nitrogen cycle and eventually produce high nitrate contents in the area. A moderate zone was found at the central west and north-east of the area. Several isolated spots at the central, central north and southeast close to Puttalam lagoon were also under moderate category (Fig. 4b). However, the DRASTIC map particularly showed that it was high vulnerable due to natural factors, the pollution risk was found to be moderate, due to the absence of land-use activities as dominated by beach sands. Given the relatively high risk in the Kalpitiya area, groundwater impacts will be a serious future concern. Therefore, it is important to consider effective policies and an institutional framework to better manage both agricultural and domestic nitrogen loadings. The institutional framework should consider an extension service to better educate farmers on good agricultural practices to optimize and minimize the use of excess chemicals in agriculture as well as improvement of sanitary systems (Jayasingha et al. 2015). Possible countermeasures are recommended to be integrated in the conservation and management plans on groundwater vulnerability, including (1) the fresh and productive groundwater zone must be clearly demarcated in water quality maps; (2) high vulnerable zones to pollution must be monitored and controlled from further expansion; (3) level of annual increase in contamination concentration must be monitored; and (4) groundwater protection zones should be established at high vulnerability of the aquifer. Additionally, land-use pattern, number of wells, population density, the trend of population increase, method of fertilizer application and amount per year, type of cultivated vegetable, climate data and sanitary systems can be used as background information for the countermeasures and management plans. It was found that the Katana area falls under low to moderately high contamination risk of groundwater, especially in the south, central south, west and north-west along the main road close to Negombo lagoon (Fig. 4c). This is mainly caused by leaking from sewage systems of dense population, coconut cultivation (fertilizer practice), permeable sandy soil and flat area.

To validate the integrated vulnerability maps of groundwater in each area, the groundwater nitrate was collected and selected. It should be noted that the $\mathrm{NO}_{3}{ }^{-}$data are primary data as directly conducted in the field through laboratory work. From each study area, it was collected in different time frame; however, there were no temporal observations in each area. Due to limited time, it should be well noted that the data of each study area were collected as one-time sampling, which represents only the season but not temporal variation of the data. Temporal distribution/time frame of the observations was not conducted for this study as temporally hydrological factors may affect the $\mathrm{NO}_{3}{ }^{-}$concentration. For this reason, it is considered as research gap, which may affect the consistency of this work. It is thus suggested that future research should carefully consider this case. The groundwater analysis for nitrate concentrations of evenly spaced 11 samples in Vanathavillu during November 2017 (second inter monsoonal season), 34 in the Kalpitiya during January 2018 (north-east monsoon season), and 26 in the Katana during July 2018 (first inter monsoon season), from dug and tube wells demonstrated that about $18 \%$ of the water samples in Vanathavillu exceeds the human affected value of $10 \mathrm{mg} / \mathrm{NO}_{3}{ }^{-}$as natural condition, while no sample was over permissible limits $(50 \mathrm{mg} / \mathrm{l})$ based on Sri Lankan Standard (SLS 614 2013).

High nitrate concentrations observed in the Kalpitiya intensified by vegetable cultivation show that about $56 \%$ of the samples are beyond $10 \mathrm{mg} / \mathrm{NO}_{3}{ }^{-}$, while about $24 \%$ over $50 \mathrm{mg} / \mathrm{l}$, Analysis of nitrate in the Katana area, which is dominated by coconuts and settlements indicate that $31 \%$ of the water samples have contents above $10 \mathrm{mg} / \mathrm{l}$, but there is no samples exceeding $50 \mathrm{mg} / \mathrm{l}$. It is well noted that natural condition of $\mathrm{NO}_{3}{ }^{-}$concentrations does not exceed $10 \mathrm{mg} / \mathrm{l}$, so that the beyond $10 \mathrm{mg} / \mathrm{l}$ is an indication of anthropogenic pollution, indiscriminate use of higher fertilizers and poor sanitation (WHO 2011). Very high nitrate content can cause blue baby syndrome in infants and gastric cancer in adults.

A validation was performed to test the accuracy and suitability of groundwater vulnerability assessment of the study areas. Above nitrate was selected as the main parameter of the initial contamination, preceding chloride and nutrient (ARGOSS 2002) to validate against the integrated vulnerability maps. Using the $\mathrm{NO}_{3}{ }^{-}$concentrations in the maps in Fig. 4, box-plots were developed to show relationships between pollution risk classes and $\mathrm{NO}_{3}{ }^{-}$concentrations and given in Fig. 5. They show that there is good relation or interaction between pollution risk classes and actual contaminant concentrations of nitrate in the study areas by following the order of classes. However, no specific correlation between vulnerability zones and $\mathrm{PO}_{4}{ }^{3-}$, TDS and chloride levels could be identified. The study has shown that there is good relationship between the groundwater vulnerability classes and $\mathrm{NO}_{3}{ }^{-}$concentrations in the areas. The nitrate can thus be used as a good indicator of aquifer deterioration fate in regard to human activities (notably coconuts, agriculture and sanitation) in the areas. It is also implied that land-use tends to be a good predictor of contamination of groundwater by nitrate. 
Fig. 5 Box plot showing relationship between groundwater pollution risk classes and groundwater nitrate concentrations for the a Vanathavillu, $\mathbf{b}$ Kalpitiya, and $\mathbf{c}$ Katana area
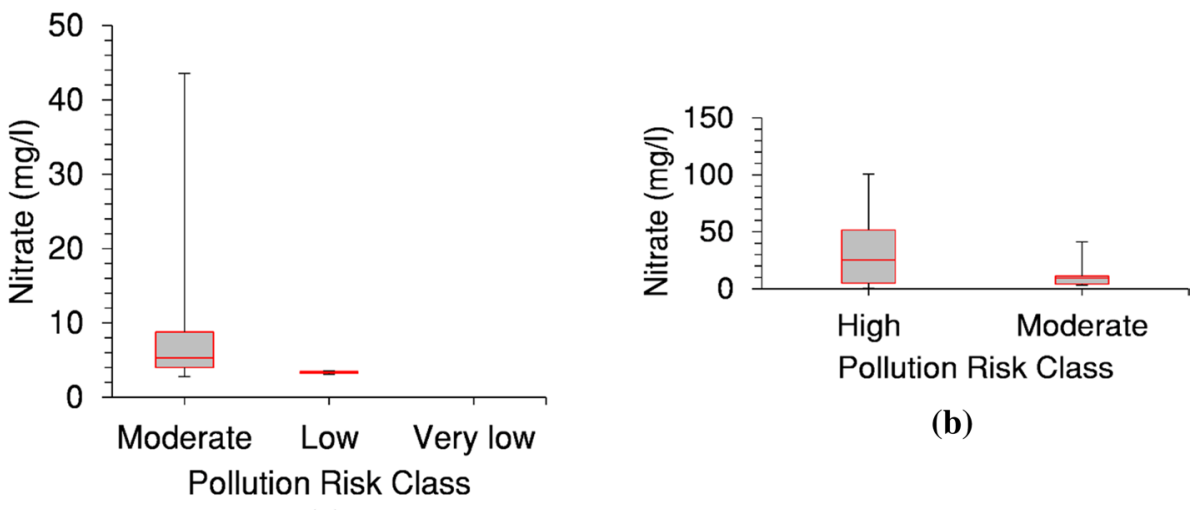

(b)

(a)

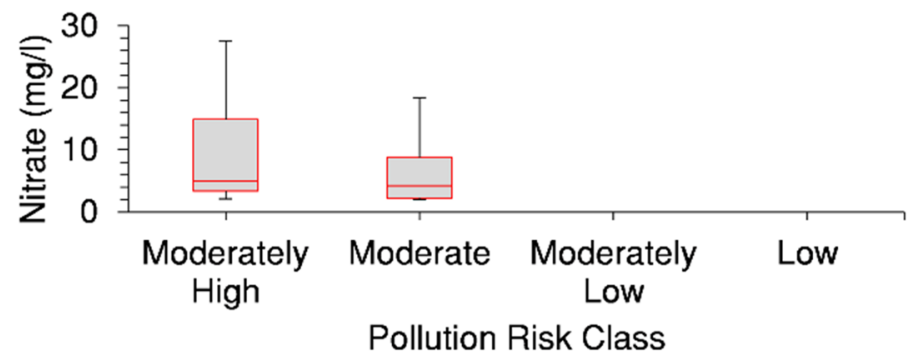

(c)

\section{Conclusions}

This study used coupled overlay—indexed DRASTIC with GIS approach to construct vulnerability maps and linearly combined with land-use parameters to predict groundwater risk. It was successfully applied to the study areas. Seven hydrogeological factors (i.e., depth to water table, recharge, aquifer media, soil media, topography, vadose zone and conductivity) have been used to visualize the maps considering weight coefficient and ratings based on local conditions. The intrinsic groundwater vulnerability of Vanathavillu ranges from low to moderate, while the Kalpitiya falls under high vulnerability and the Katana is under moderate to high vulnerability. The outputs of the integrated maps reveal that groundwater of the areas under study varies from very low to high risk of contamination. A higher risk ( $82 \%$ ) has been identified at the Kalpitiya area due to very shallow groundwater level $(1-5 \mathrm{~m})$, over pumping for vegetable cultivation associated with excessive fertilizer and chemical application, permeable sandy soil and very flat slope $(<2 \%)$. The moderate contamination risk $(13 \%)$ in the center, west and southwest of Vanathavillu could be due to relatively deep groundwater tables, possible seepage upward from underlying limestone aquifer, less permeable red earth and gentle slope (2-6\%). The majority of the Katana area falls under moderately high contaminated particularly in the southward and middle areas which are mainly dominated by sand (shallow and slightly deep groundwater) and populous settlements (improper sanitation). Higher nitrate contents exceeding the natural condition of $10 \mathrm{mg} / \mathrm{l}$ was found in the Kalpitiya compared to Vanathavillu and Katana. The main sources of nitrate originate from fertilizer application and domestic waste. A good agreement between nitrate and the pollution risk classes from the integrated vulnerability maps indicate that nitrate can be used as an indicator of aquifer degradation inherent with human activities in the coastal areas. Therefore, more attention should be focused to improve fertilizer and chemical application and sanitary systems and to establish groundwater quality monitoring network to optimize anthropological stresses on groundwater.

Funding The study was supported by NORAD Water and Society (WaSo-Asia) Project Program from Norwegian government.

\section{Declarations}

Conflict of interest The authors declare that there is no conflict of interest.

Open Access This article is licensed under a Creative Commons Attribution 4.0 International License, which permits use, sharing, adaptation, distribution and reproduction in any medium or format, as long as you give appropriate credit to the original author(s) and the source, provide a link to the Creative Commons licence, and indicate if changes were made. The images or other third party material in this article are included in the article's Creative Commons licence, unless indicated otherwise in a credit line to the material. If material is not included in 
the article's Creative Commons licence and your intended use is not permitted by statutory regulation or exceeds the permitted use, you will need to obtain permission directly from the copyright holder. To view a copy of this licence, visit http://creativecommons.org/licenses/by/4.0/.

\section{References}

Al-Adamat RAN, Foster IDL, Baban SMJ (2003) Groundwater vulnerability and risk mapping for the basaltic aquifer of the Azraq basin of Jordan using GIS, remote sensing and DRASTIC. Appl Geogr 23:303-324

Aller L, Bennett T, Lehr JH, Petty RJ (1987) DRASTIC: a standardized system for evaluation groundwater pollution potential using hydrogeologic settings. EPA/600/2-87/035, U.S. Environmental Protection Agency, Ada, Oklahoma, p.7-20.

Annual Performance Report and Accounts (2016). District secretariat_Puttalam. Available at: https://www.parliament.lk/uploads/ documents/paperspresented/performance-report-district-secre tariat-puttalam-2016.pdf, accessed 23 March, 2018.

ARGOSS (2002) Assessing risk to groundwater from onsite sanitation: scientific review and case studies. British Geological Survey Commissioned Report, CR/02/079N. 4411pp. BGS Keyworth, England.

Babiker IS, Mohamed AAM, Hiyama T, Kato K (2005) A GIS-based DRASTIC model for assessing aquifer vulnerability in Kakamigahara Heights, Gifu Prefecture, central Japan. Sci Total Environ 345(2005):464-8601

Cooray PG (1982) Geological map of Sri-Lanka. Available at: http:// esdac.jrc.ec.europa.eu/content/geological-map-sri-lanka, accessed 25 May, 2017

Davies J, Herbert R (1988) The hydrogeology of the Miocene sedimentary belt of Sri Lanka. J Geol Soc Sri Lanka 1:45-63

Department of Census and Statistics (2012). Statistical abstract 2016: population. Available at: http://www.statistics.gov.lk/Abstract20 16/index.asp?page $=$ chap2, accessed 04 August 2017.

Department of Census and Statistics (2016). Statistical abstract 2016: population. Available at: http://www.statistics.gov.lk/Abstract20 16/index.asp?page $=$ chap 1 , accessed 04 August 2017.

Ducci D (2010) Aquifer vulnerability assessment methods: the non-independence of parameters problem. J Water Res Prot 2010(2):298-308. https://doi.org/10.4236/jwarp.2010.24034

Edirisinghe EANV, Karunarathne GRR, Samarakoon ASMNB, Pitawala HMTGA, Dharmagunawardhane HA, Tilakarathna IANDP (2016) Assessing causes of quality deterioration of groundwater in Puttalam, Sri Lanka, using isotope. J Isotopes Environ Health Stu. https://doi.org/10.1080/10256016.2015.1127918

Farjad B., Shafri, H. Z. B. M, Mohamed, T. A., Pirasteh, S., \& Wijesekara, N. (2012). Groundwater intrinsic vulnerability and risk mapping. Proceedings of water management, volume 165 , issue WMB, https://doi.org/10.1680/wama.10.00018, Serdang, Malaysia, pp. 441-450.

Fetter CW (2001) Applied Hydrogeology. $4^{\text {th }}$ ed. University of Wisconsin Oshkosh, United States of America: Prentice-Hall, Inc., Upper Saddle River, New Jersey 07458, 598 p., ISBN: 0-13-088239-9.

Foster S, Hirata R, Gomes D, D'Elia M, Paris M (2002) Groundwater quality protection: a guide for water utilities, municipal authorities, and environment agencies. The International Bank for Reconstruction and Development/The World Bank, Washington, D.C.

Gunawardena ERN, Pabasara PKD (2016) A framework for groundwater policy for Sri Lanka. Symposium proceedings of groundwater availability and use in the dry zone of Sri Lanka. Cap-Net Lanka, PGIA, Peradeniya, Sri Lanka.
Gupta J, Vegelin C (2016) Sustainable development goals and inclusive development. Int Environ Agree Politics Law Econo 16(3):433-448

Jayasekera DL, Kaluarachchi JJ, Villholth KG (2008) Groundwater quality impacts due to population growth and land-use exploitation in the coastal aquifers of Sri Lanka. Conference Proceedings, Abstracts of the presentations given in Session 2 of the UCOWR Conference (2008). Paper43.

Jayasekera DL, Kaluarachch JJ, Villholth KG (2011) Groundwater stress and vulnerability in rural coastal aquifers under competing demands: a case study from Sri Lanka. Environ Monit Assess (2011), Issue 176. College of Engineering, Utah State University, 4100 Old Main Hill, Logan, UT 84322-4100, USA: Springer Science+Business Media B.V. 2010, pp. 13-30.

Jayasingha P, Pitawala A, Dharmagunawardhane HA (2011) Vulnerability of coastal aquifers due to nutrient pollution from agriculture Kalpitiya. Article of water, air, soil, pollution, Sri Lanka. https://doi.org/10.1007/s11270-010-0728-y

Jayasingha P, Pitawala A, Dharamagunawardhane HA, Welagedara AS, Jayathilaka K (2015). Applications of GIS and remote sensing for sustainable use and management of groundwater: a case study from the northwestern coastal area of Sri Lanka. Surface and Sub-surface Water in Asia-Issues and Perspectives, Subramanian, V. (Ed.). The Netherlands: IOS Press, DOI: https:// doi.org/10.3233/978-1-61499-540-1-72, ISBN 978-1-61499_ 540-1 (online), Available at: http://ebooks.iospress.n1/book/ surface-and-sub-surface-water-in-asia-issues-and-perspectiv es, accessed 28 November, 2017.

Joshi P, Gupta PK (2018) Assessing groundwater resource vulnerability by coupling GIS based DRASTIC and solute transport model in Ajmer District, Rajasthan. J Geol Soc India 92:101-106

Kumar P, Bansoda BKS, Debnatha SK, Thakur PK, Ghanshyam C (2015) Index-based groundwater vulnerability mapping models using hydrogeological settings: a critical evaluation. J Environ Impact Asses Rev 51:38-49

Kumar P, Thakur PK, Bansod BKS, Debnath SK (2017) Multicriteria evaluation of hydro-geological and anthropogenic parameters for the groundwater vulnerability assessment. J Environ Moni Asses 189(11):1-24. https://doi.org/10.1007/ s10661-017-6267-x

Kumar P, Thakur PK, Bansod BKS, Debnath SK (2018) Groundwater: a regional resource and a regional governance. Environ Dev Sustain 20(3):1133-1151

Kumar P, Thakur P, Debnath S (2020) Groundwater vulnerability assessment and mapping using DRASTIC model. CRC Press, Boca Raton. https://doi.org/10.1201/9780429287862

Kuruppuarachchi DSP, Fernando WARN (1999) Impact of agriculture on groundwater quality: leaching of fertilizers to groundwater in Kalpitiya Peninsula. J Soil Sci Soc Sri Lanka 11:9-16

Lawrence AR, Chilton PJ, Kuruppuarachchi DSP (1988) Review of the pollution threat to groundwater in Sri Lanka. J Geolo Soc Sri Lanka 1988(1):85-92

Lawrence AR, Dharmagunawardena HA (1981) The Groundwater resources of the Vanathavillu basin. Published report. Water Resources Board Groundwater Division, Colombo, Sri Lanka.

Lerner DN (2002) Identifying and quantifying urban recharge: a review. Hydrogeol J 10(1):143-152

Lobo-Ferraira JP, Olivereira MM (2004) Groundwater vulnerability assessment in Portugal. J Geofisica Int 43(4):541-550

Lodwick WA, Monson W, Svoboda L (1990) Attribute error and sensitivity analysis of map operations in geographical information systems: suitability analysis. Int J Geo Info Sys 4(4):413-428

Mato RRAM (2002) Groundwater pollution in urban Dar es Salaam, Tanzania: assessing vulnerability and protection priorities. $\mathrm{PhD}$ Thesis, Eindhoven University of Technology, Tanzania, 194p.

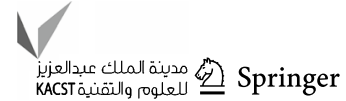


Moormann FR, Panabokke CR (1961) Soils of Ceylon: a new approach to the identification and classification of the most important soil groups of Ceylon. Published report. Eastern paper mills corporation, Valaichohbnai, Ceylon, 4(62): 2251-180.

Morris BL, Lawrence ARL, Chilton PJC, Adams B, Calow RC, Klinck BA (2003) Groundwater and its susceptibility to degradation: a global assessment of the problem and options for management. Early Warning and Assessment Report Series, RS. 03-3. Nairobi, Kenya: United Nations Environment Programme, UNEP.

Napolitano P, Fabbri AG (1996) Single-parameter sensitivity analysis for aquifer vulnerability assessment using DRASTIC and SINTACS. HydroGIS 96: application of geographical information systems in hydrology and water resources management. Proc Vienna Conf IAHS Pub 235:559-566

Neshat A, Pradhan B (2017) Evaluation of groundwater vulnerability to pollution using DRASTIC framework and GIS. Arab J Geosci 10:501

NRC (1993) Groundwater vulnerability assessment: contamination potential under conditions of uncertainties. National Academy Press, Washington, D.C., p 227

Panabokke CR (2007) Groundwater conditions in Sri Lanka. A geomorphic perspective. 47/5, Maitland Place, Colombo 7, Sri Lanka: National Science Foundation of Sri Lanka. ISBN: 978-955-590-079-9.

Panagopoulos GP, Antonakos AK, Lambrakis NJ (2006) Optimization of the DRASTIC method for groundwater vulnerability assessment via the use of simple statistical methods and GIS. Hydrogeol J 14(6):894-911

Putra DPE (2007) The Impact of urbanization on groundwater quality: a case study in Yogyakarta City-Indonesia. PhD thesis. Mitteilungen zur Ingenieur geologie und Hydrogeologie, Heft 96, 148 S, Okt 2007, Herausegeben vom Lehrstuhl fur Ingenieur geologie und Hydrogeologie, Univ.-Prof. Dr. R. Azzam, RWTH Aachen, Germany. No. ISBN: 3-86130-281-0.

Ranjan SP (2005) Assessment of groundwater vulnerability in Walawe river basin, Sri Lanka. Engineer: Journal of the Institution of Engineers, Sri Lanka, 38(1).

Rahman A (2008) A GIS based DRASTIC model for assessing groundwater vulnerability in shallow aquifer in Aligarh. India Appl Geo 28(1):32-53. https://doi.org/10.1016/j.apgeog.2007.07.008

Ratha P (2015) Groundwater vulnerability of Ngemplak and Kalasan in north-east of Sleman district, Yogyakarta, Indonesia. Master Thesis. Yogyakarta Special Province, Indonesia: University of Gadjah Mada.

Sarukkalige PR, Das Gupta A, Kazama S, Sawamoto M (2007) Assessment of aquifer-land use composite vulnerability in Walawe River Basin Sri Lanka. Asian J Water Environ Poll 4(2):1-10
Sener E, Sener S, Davraz A (2009) Assessment of aquifer vulnerability based on GIS and DRASTIC methods: a case study of the Senirkent-Uluborlu Basin (Isparta, Turkey). Hydrogeol J 2009(17):2023-2035

SLS 614 (2013). Specification for potable water physical and chemical requirements, $1^{\text {st }}$ revision, Sri Lankan Standards Institution for potable water. Available at: http://www.slsi.lk/web/index.php? option=com_slstandards, accessed December 30, 2017.

Soil Conservation Service (SCS) (1986). Urban hydrology for small watersheds, $2^{\text {nd }}$ ed.. Technical Release 55 (TR-55). Washington, DC: United States Department of Agriculture (USDA). 164p.

Tengberg A (2015) World water week 2015. Environ Dev Sustain 17(6): 1247-1249

Turc L (1954) Le bilan d'eau des sols: relation entre les précipitations l'évaporation et l'écoulement. Annales agronomiques, pp: 491-595.

Vithanage M, Mikunthan T, Pathmarajah S, Arasalingam S, Manthrithilake $\mathrm{H}$ (2014) Assessment of nitrate-N contamination in the Chunnakam aquifer system, Jaffna Peninsula Sri Lanka. Springerplus 3(1):271. https://doi.org/10.1186/2193-1801-3-271

Vrba J, Zaporozec A (ed.) (1994) Guidebook on mapping groundwater vulnerability. International Association of Hydrogeologists, 16: 28-48.

WHO (2011) Guideline for Drinking water quality, $4^{\text {th }}$ ed., Geneva, World Health Organization, 541p. ISBN 9789241548151.

Yin L, Zhang E, Wang X, Wenninger J, Dong J, Guo L (2012) A GISbased DRASTIC model for assessing groundwater vulnerability in the Ordos Plateau China. Environ Earth Sci. https://doi.org/10. $1007 / \mathrm{s} 12665-012-1945-\mathrm{z}$

Zaporozec A (ed) (2002) Groundwater contamination inventory. IHPVI, series on groundwater No.2. UNESCO, United States of America

Zhang R, Hamerlinck JD, Gloss SP, Munn L (1996) Determination of nonpoint-source pollution using GIS and numerical models. J Environ Qual 25:411-418

Zhang R, Pu L, Li J, Zhang J, Xu Y (2015) Landscape ecological security response to land use change in the tidal flat reclamation zone, China. J Environ Monit Assess 188(1):1-10

Publisher's Note Springer Nature remains neutral with regard to jurisdictional claims in published maps and institutional affiliations. 